\title{
ROTAVIRUS GENOTYPES CIRCULATING IN BRAZIL, 2007-2012: IMPLICATIONS FOR THE VACCINE PROGRAM
}

\author{
Adriana LUCHS(1), Audrey CILLI(1), Simone Guadagnucci MORILLO(1), Rita de Cássia Compagnoli CARMONA(1) \& \\ Maria do Carmo Sampaio Tavares TIMENETSKY(1)
}

\begin{abstract}
SUMMARY
Regarding public health in Brazil, a new scenario emerged with the establishment of universal rotavirus (RV) vaccination programs. Herein, the data from the five years of surveillance (2007-2012) of G- and P-type RV strains isolated from individuals with acute gastroenteritis in Brazil are reported. A total of 6,196 fecal specimens were investigated by ELISA and RT-PCR. RVs were detected in $19.1 \%(1,181 / 6,196)$. The peak of RV incidence moved from June-August to September. RV was detected less frequently (19.5\%) among children $\leq 5$ years than in older children and adolescents (6-18 years) (40.6\%). Genotype distribution showed a different profile for each year: G2P[4] strains were most prevalent during 2007-2010, G9P[8] in 2011, and G12P[8] in 2012. Mixed infections $(\mathrm{G} 1+\mathrm{G} 2 \mathrm{P}[4], \mathrm{G} 2+\mathrm{G} 3 \mathrm{P}[4]+\mathrm{P}[8], \mathrm{G} 2+\mathrm{G} 12 \mathrm{P}[8])$, unusual combinations (G1P[4], G2P[6]), and rare strains (G3P[3]) were also identified throughout the study period. Widespread vaccination may alter the RV seasonal pattern. The finding of RV disease affecting older children and adolescents after vaccine implementation has been reported worldwide. G2P[4] emergence most likely follows a global trend seemingly unrelated to vaccination, and G12, apparently, is emerging in the Brazilian population. The rapidly changing RV genotype patterns detected during this study illustrate a dynamic population of co-circulating wildtype RVs in Brazil.
\end{abstract}

KEYWORDS: Rotavirus; Genotypes; Surveillance; Vaccine; Gastroenteritis.

\section{INTRODUCTION}

Rotavirus (RV) disease is a global public health concern, accounting for over half a million deaths and two million hospitalizations each year $^{36,42}$. RVs are classified in a binary system based upon the main neutralization antigens, namely, the spike protein (VP4) and the major outer capsid glycoprotein (VP7). VP7 and VP4 nucleotide sequences define $\mathrm{G}$ and $\mathrm{P}$ genotypes, respectively, and carry independent neutralization-specific epitopes. To date, 27 G genotypes (G1-G27) and $37 \mathrm{P}$ genotypes (P[1]-P[35]) have been described ${ }^{30,45}$. Globally, most human RVs have the genotype combination G1P[8], G2P[4], G3P[8], $\mathrm{G} 4 \mathrm{P}[8]$ or G9P [8], and studies from all around the world have recently shown a high prevalence of G12 strain and its association with multiple VP4 genotypes ${ }^{5}$.

Two safe and effective RV vaccines (Rotarix ${ }^{\mathrm{TM}}$, GlaxoSmithKline Biologicals, Belgium; and RotaTeq ${ }^{\mathrm{TM}}$, Merck Inc., USA) have been licensed in approximately 100 countries worldwide since 2006 . These vaccines have already been incorporated into the routine immunization programs in many countries of the Americas (including Brazil) and Europe, as well as in Australia and South Africa ${ }^{48}$. Brazil's national immunization program introduced Rotarix ${ }^{\mathrm{TM}}$ vaccine in the childhood immunization schedule in March 2006. From 2007 to 2010, administrative coverage with the two-dose series of RV vaccine ranged from $80 \%$ to $84 \%$ in the country ${ }^{15}$, and $22 \%$ reduction in diarrhea-related mortality was observed in children $<5$ years during 2007-2009 ${ }^{12}$. With the 2009 World Health Organization (WHO) recommendation for the global use of $R V$ vaccines, it is anticipated that these vaccines will soon be introduced more widely in immunization programs globally 5 .

The primary goal of most RV strain surveillance programs is to genotype the co-circulating RVs before the introduction of vaccine and to monitor vaccine effectiveness ${ }^{5,28,32}$. Virtually, all such studies are conducted on infants ${ }^{43}$. The RV genotypic diversity in the general population has received much less attention. In addition, seasonal changes of the predominant RV strains in children in a given geographical region and the cross-border migration of $\mathrm{RV}$ strains due to population movements have also been documented ${ }^{4}$. However, the issue of whether the introduction of new RV strains in children results in disease across all age groups is not commonly addressed.

A new scenario emerged in Brazil with the establishment of a universal RV vaccination program, and the consequences on the epidemiology of RV infections are still unpredictable ${ }^{13}$. Continued 
LUCHS, A.; CILLI, A.; MORILLO, S.G.; CARMONA, R.C.C. \& TIMENETSKY, M.C.S.T. - Rotavirus genotypes circulating in Brazil, 2007-2012: implications for the vaccine program. Rev. Inst. Med. Trop. Sao Paulo, 57(4): 305-13, 2015.

genotype surveillance is needed to better understand the spread of RV in the broader community. The aim of this study was to describe the $\mathrm{G}$ and P types of RV strains isolated in Brazil during five years of surveillance (2007-2012).

\section{MATERIALS AND METHODS}

From June 2007 to June 2012, a total of 6,196 fecal specimens were collected from children $\leq 5$ years of age, school-age children and adolescents (6 - 18 years), adults (19 - 59 years), and elderly patients ( $\geq 60$ years) with acute gastroenteritis. Epidemiological data (age, date of diarrhea onset, date of sample collection) were not available for all patients, probably due to insufficient healthcare worker education and information. The specimens were stored at $-20{ }^{\circ} \mathrm{C}$ until tested for RV and characterized.

This is a retrospective and descriptive study conducted with clinical samples. Stool samples from patients with acute gastroenteritis were sent to the Enteric Diseases Laboratory of the Adolfo Lutz Institute, a regional reference center for RV surveillance, credentialed by the Health Ministry of Brazil, and a member of the Acute Diarrhea Disease Monitoring Program from the State Department of Health. The aim of this program is the early detection of diarrhea outbreaks with national scope. In this study, clinical samples from Sao Paulo (SP), Mato Grosso (MT), Mato Grosso do Sul (MS), Parana (PR), Tocantins (TO), Goias (GO), Santa Catarina (SC) States, and Federal District (DF) were analyzed (Fig. 1).

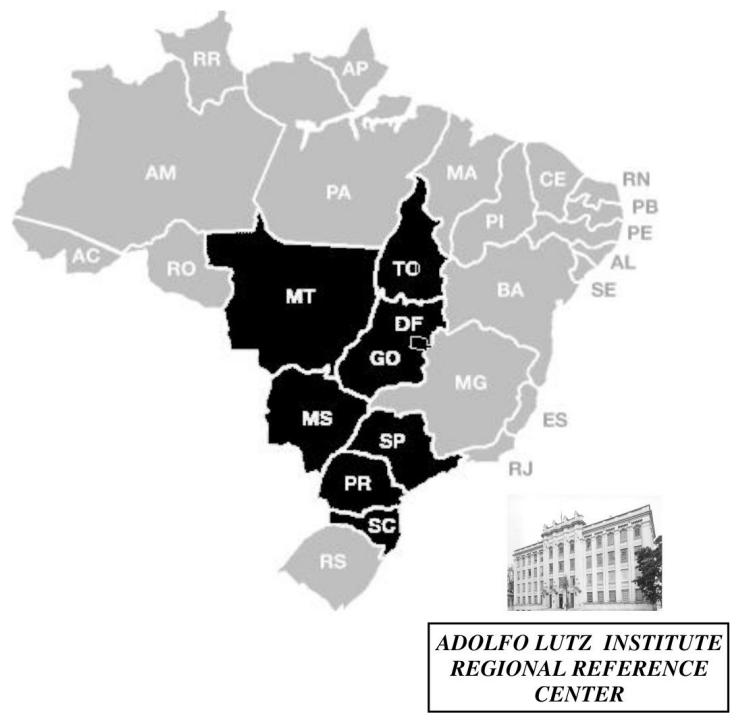

Fig. 1 - The States highlighted in black collected stool samples from patients with acute gastroenteritis and sent them to the Enteric Diseases Laboratory of the Adolfo Lutz Institute, regional reference center for rotavirus surveillance, member of Acute Diarrhea Disease Monitoring Program and its national scope. Abbreviations represent the names of Brazilian States: Acre (AC), Alagoas (AL), Amapa (AP), Amazonas (AM), Bahia (BA), Ceara (CE), Distrito Federal (DF), Espirito Santo (ES), Goias (GO), Maranhao (MA), Mato Grosso (MT), Mato Grosso do Sul (MS), Minas Gerais (MG), Para (PA), Paraiba (PB), Parana (PR), Pernambuco (PE), Piaui (PI), Rio de Janeiro (RJ), Rio Grande do Norte (RN), Rio Grande do Sul (RS), Rondonia (RO), Roraima (RR), Santa Catarina (SC), Sao Paulo (SP), Sergipe (SE), and Tocantins (TO).

All specimens were screened for RV using a commercial enzymelinked immunosorbent assay (ELISA) (Premier Rotaclone, Meridian
Diagnostics, Cincinnati, OH, USA) with monoclonal antibodies specific for group A human RV, according to the manufacturer's protocol. RV double-stranded RNA (dsRNA) was extracted from the fecal samples (diluted in TRIS-HCL $0.001 \mathrm{M}, \mathrm{pH} 7.3$ to obtain a $10 \%$ suspension) using QIAamp® Viral RNA Mini kit (Qiagen, Valencia, CA, USA), according to the manufacturer's instructions. The extracted dsRNA was subjected to $\mathrm{G}$ and $\mathrm{P}$ typing by multiplex reverse transcription-polymerase chain reaction (RT-PCR) with type-specific primers following previously described protocols ${ }^{16-18,27}$.

\section{RESULTS}

The RV was detected in 1,181 (19.1\%) of 6,196 specimens collected from children, adults, and elderly patients in Brazil during a five-year period. RV infection was found predominantly in the winter and in drier months. The incidence peaked in September (Fig. 2). The detection rate varied according to the year: $23.2 \%(173 / 746)$ in $2007 ; 25.9 \%(247 / 954)$ in $2008 ; 2.3 \%(20 / 877)$ in $2009 ; 29.8 \%(544 / 1,824)$ in $2010 ; 15.8 \%$ $(176 / 1,111)$ in 2011 ; and $3.1 \%$ (21/684) in 2012. The age or date of birth was provided by $1,150(97.4 \%)$ of 1,181 patients who tested positive for RV. RV disease was detected mainly in individuals $\leq 18$ years of age, and peaks of incidence occurred from six to 18 years (215 [40.6\%] of 529). However, RV infection was also detected in adults and elderly patients (Table 1).

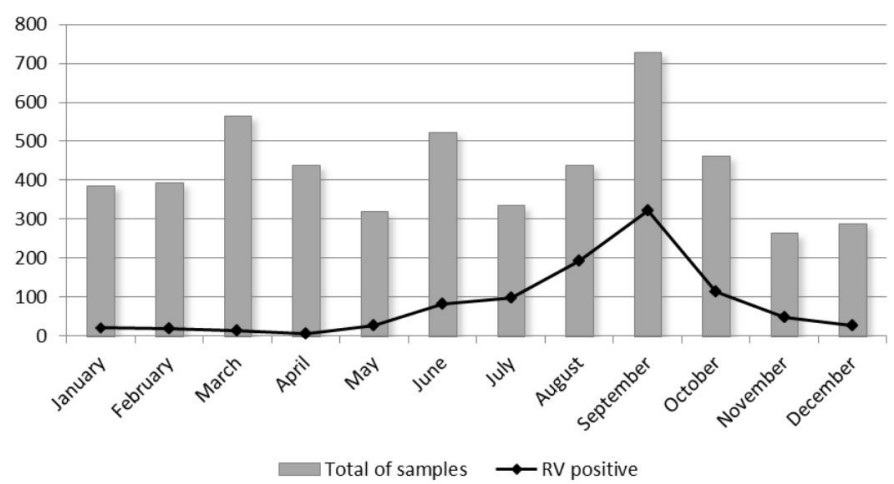

Fig. 2 - Temporal distribution of rotavirus strains from children, school children and adolescents, adults, and elderly patients with acute diarrhea, Brazil, 2007-2012.

A total of $1,054(89.2 \% ; 1,054 / 1,181) \mathrm{RV}$-positive samples were randomly selected for determination of $\mathrm{G}$ and $\mathrm{P}$ genotypes by an RTPCR assay. Both RV G and P types could be established in 945 (89.6\%; 945/1,054) strains, and 37 different $P$ and $G$ associations were detected. The distribution of RV VP7 types in Brazil during this five-year period showed that G2 was the most prevalent genotype from 2007 to 2010; however it was displaced by G9 in 2011. In 2012, the emergence of G12 strains was observed. The uncommon genotypes G8 and G10 were detected between 2009 and 2011, and in 2012, respectively. Considering the VP4 protein, $\mathrm{P}$ [4] was predominant during 2007-2008, and 2010, P[6] in 2009, and $\mathrm{P}[8]$ in 2011-2012 (Table 2).

Four of the five most globally common strains, G1P[8], G2P[4], G3P[8] and G9P[8] were identified, which represented $74.6 \%$ of all typed RV strains. Curiously, the $5^{\text {th }}$ most common strain, G4P[8], was not identified during the study period. Genotype distribution showed a different profile for each year: G2P[4] being most 
Table 1

Distribution of RV-positive samples according to age group, Brazil, 2007-2012

\begin{tabular}{|c|c|c|c|c|}
\hline Age (years) & RV positive (No.) & Total of samples (No.) & $\mathrm{RV}$ positive $(\%)$ & Total values (\%) \\
\hline$\leq 5$ & 821 & 4,213 & $19.5 \%$ & $69.5 \%$ \\
\hline $6-18$ & 215 & 529 & $40.6 \%$ & $18.2 \%$ \\
\hline $19-59$ & 99 & 1004 & $10.0 \%$ & $8.4 \%$ \\
\hline$\geq 60$ & 15 & 202 & $7.4 \%$ & $1.3 \%$ \\
\hline$*$ & 31 & 248 & $12.5 \%$ & $2.6 \%$ \\
\hline Total & 1181 & 6196 & $19.1 \%$ & $100 \%$ \\
\hline
\end{tabular}

* Patient age not known.

Table 2

P and G types of RV strains from children, school children and adolescents, adults, and elderly with acute diarrhea, Brazil, 2007-2012

\begin{tabular}{|c|c|c|c|c|c|c|c|}
\hline \multirow{3}{*}{ Genotypes } & \multicolumn{7}{|c|}{ Year } \\
\hline & 2007 & 2008 & 2009 & 2010 & 2011 & 2012 & Total \\
\hline & No. $(\%)$ & No. (\%) & No. $(\%)$ & No. $(\%)$ & No. $(\%)$ & No. $(\%)$ & No. $(\%)$ \\
\hline \multicolumn{8}{|c|}{ Common human rotavirus genotypes } \\
\hline G1P[8] & $22(17.9)$ & $5(2.7)$ & - & $23(4.3)$ & - & - & $50(4.7)$ \\
\hline $\mathrm{G} 2 \mathrm{P}[4]$ & $74(60.3)$ & $140(77.3)$ & $5(27.8)$ & $325(60.3)$ & $29(17.5)$ & $1(3.8)$ & $574(54.2)$ \\
\hline G3P[8] & - & $1(0.5)$ & $3(16.4)$ & $43(8.0)$ & $18(10.8)$ & $3(11.5)$ & $68(6.4)$ \\
\hline G9P[8] & $14(11.4)$ & $1(0.5)$ & - & $13(2.4)$ & $66(39.8)$ & $2(7.7)$ & $96(9.1)$ \\
\hline \multicolumn{8}{|c|}{ Reassortment among common human rotavirus genotypes } \\
\hline G1P[4] & $1(0.8)$ & - & - & $3(0.5)$ & - & - & $4(0.4)$ \\
\hline G3P[4] & - & - & - & $22(4.1)$ & - & - & $22(2.1)$ \\
\hline$\underline{\mathrm{G} 9 \mathrm{P}[4]}$ & - & - & - & $1(0.2)$ & - & - & $1(0.1)$ \\
\hline \multicolumn{8}{|c|}{ Potential zoonotic rotavirus genotypes } \\
\hline G3P[3] & - & - & - & - & $1(0.6)$ & - & $1(0.1)$ \\
\hline G3P[6] & - & - & - & $2(0.4)$ & $4(2.4)$ & - & $6(0.6)$ \\
\hline G8P[6] & - & - & $5(27.8)$ & - & - & - & $5(0.5)$ \\
\hline $\mathrm{G} 12 \mathrm{P}[9]$ & - & - & $1(5.6)$ & - & $1(0.6)$ & $1(3.8)$ & $3(0.3)$ \\
\hline \multicolumn{8}{|c|}{ Possible human-animal hybrid rotavirus genotypes } \\
\hline G2P[6] & $1(0.8)$ & - & - & - & - & - & $1(0.1)$ \\
\hline G8P[4] & - & - & - & $4(0.7)$ & $1(0.6)$ & - & $5(0.5)$ \\
\hline G12P[4] & - & - & - & - & - & $1(3.8)$ & $1(0.1)$ \\
\hline G12P[6] & - & - & - & - & $1(0.6)$ & - & $1(0.1)$ \\
\hline$\underline{\mathrm{G} 12 \mathrm{P}[8]}$ & - & $1(0.5)$ & - & - & $30(18.1)$ & $12(46.5)$ & $43(4.1)$ \\
\hline \multicolumn{8}{|c|}{ Mixed infections (single G-type with two or more P-types) } \\
\hline $\mathrm{G} 1 \mathrm{P}[4]+\mathrm{P}[8]$ & - & - & - & $1(0.2)$ & - & - & $1(0.1)$ \\
\hline $\mathrm{G} 2 \mathrm{P}[4]+\mathrm{P}[8]$ & $1(0.8)$ & - & - & $4(0.7)$ & - & - & $5(0.5)$ \\
\hline $\mathrm{G} 2 \mathrm{P}[4]+\mathrm{P}[6]$ & - & - & $1(5.6)$ & $2(0.4)$ & - & - & $3(0.3)$ \\
\hline $\mathrm{G} 3 \mathrm{P}[4]+\mathrm{P}[6]$ & - & - & - & $1(0.2)$ & - & - & $1(0.1)$ \\
\hline G3P[4]+P[8] & - & - & - & $1(0.2)$ & - & - & $1(0.1)$ \\
\hline G9P[4]+P[8] & $1(0.8)$ & - & - & - & - & - & $1(0.1)$ \\
\hline G9P[6]+P[8] & - & - & $1(5.6)$ & - & - & - & $1(0.1)$ \\
\hline
\end{tabular}


LUCHS, A.; CILLI, A.; MORILLO, S.G.; CARMONA, R.C.C. \& TIMENETSKY, M.C.S.T. - Rotavirus genotypes circulating in Brazil, 2007-2012: implications for the vaccine program. Rev. Inst. Med. Trop. Sao Paulo, 57(4): 305-13, 2015.

Table 2

P and G types of RV strains from children, school children and adolescents, adults, and elderly with acute diarrhea, Brazil, $2007-2012$ (cont.)

\begin{tabular}{|c|c|c|c|c|c|c|c|}
\hline \multirow{3}{*}{ Genotypes } & \multicolumn{7}{|c|}{ Year } \\
\hline & 2007 & 2008 & 2009 & 2010 & 2011 & 2012 & Total \\
\hline & No. $(\%)$ & No. $(\%)$ & No. $(\%)$ & No. $(\%)$ & No. $(\%)$ & No. $(\%)$ & No. $(\%)$ \\
\hline \multicolumn{8}{|c|}{ Mixed infections (multiple G-types with single P-type) } \\
\hline $\mathrm{G} 1+\mathrm{G} 2 \mathrm{P}[4]$ & - & - & - & $18(3.3)$ & - & - & $18(1.7)$ \\
\hline G1+G9P[8] & - & - & - & $3(0.5)$ & - & - & $3(0.3)$ \\
\hline $\mathrm{G} 2+\mathrm{G} 3 \mathrm{P}[4]$ & - & - & - & $11(2.0)$ & - & - & $11(1.0)$ \\
\hline G2+G3P[8] & - & - & - & $2(0.4)$ & - & - & $2(0.2)$ \\
\hline G2+G9P[4] & $1(0.8)$ & - & - & - & - & - & $1(0.1)$ \\
\hline G2+G9P[8] & - & - & - & $2(0.4)$ & - & - & $2(0.2)$ \\
\hline $\mathrm{G} 2+\mathrm{G} 12 \mathrm{P}[4]$ & - & - & - & - & - & $1(3.8)$ & $1(0.1)$ \\
\hline G2+G12P[8] & - & - & - & - & $1(0.6)$ & - & $1(0.1)$ \\
\hline G2+G3+G9P[8] & - & - & - & $1(0.2)$ & - & - & $1(0.1)$ \\
\hline $\mathrm{G} 1+\mathrm{G} 2+\mathrm{G} 3 \mathrm{P}[4]$ & - & - & - & $3(0.5)$ & - & - & $3(0.3)$ \\
\hline \multicolumn{8}{|c|}{ Mixed infections (multiple G- and P-types) } \\
\hline G1+G9P[4]+P[8] & - & - & - & $1(0.2)$ & - & - & $1(0.1)$ \\
\hline G2+G3P[4]+P[6] & - & - & - & $3(0.5)$ & - & - & $3(0.3)$ \\
\hline $\mathrm{G} 2+\mathrm{G} 3 \mathrm{P}[4]+\mathrm{P}[8]$ & - & - & - & $2(0.4)$ & - & - & $2(0.2)$ \\
\hline \multicolumn{8}{|c|}{ Partially typed rotavirus strains } \\
\hline $\mathrm{G} 1 \mathrm{P}[\mathrm{NT}]$ & $1(0.8)$ & $1(0.5)$ & - & $5(0.9)$ & - & - & $7(0.7)$ \\
\hline G1+G9P[NT $]$ & - & - & - & $2(0.4)$ & - & - & $2(0.2)$ \\
\hline G1+G2+G3P[NT] & - & - & - & - & $1(0.6)$ & - & $1(0.1)$ \\
\hline $\mathrm{G} 2 \mathrm{P}[\mathrm{NT}]$ & $4(3.2)$ & $20(11.0)$ & - & $5(0.9)$ & $3(1.8)$ & - & $32(3.0)$ \\
\hline $\mathrm{G} 2+\mathrm{G} 12 \mathrm{P}[\mathrm{NT}]$ & - & - & - & - & - & $1(3.8)$ & $1(0.1)$ \\
\hline G3P[NT] & - & - & - & $2(0.4)$ & $1(0.6)$ & $1(3.8)$ & $4(0.4)$ \\
\hline $\mathrm{G} 3+\mathrm{G} 12 \mathrm{P}[\mathrm{NT}]$ & - & - & - & - & $2(1.2)$ & - & $2(0.2)$ \\
\hline $\mathrm{G} 9 \mathrm{P}[\mathrm{NT}]$ & $3(2.4)$ & - & - & $2(0.4)$ & $2(1.2)$ & - & $7(0.7)$ \\
\hline G10P[NT $]$ & - & - & - & - & - & $1(3.8)$ & $1(0.1)$ \\
\hline $\mathrm{G} 12 \mathrm{P}[\mathrm{NT}]$ & - & $1(0.5)$ & - & - & $1(0.6)$ & $2(7.7)$ & $4(0.4)$ \\
\hline GNTP[4] & - & $5(2.7)$ & - & $23(4.3)$ & $4(2.4)$ & - & $32(3.0)$ \\
\hline GNTP[6] & - & - & $1(5.6)$ & $1(0.2)$ & - & - & $2(0.2)$ \\
\hline GNTP[4]+P[6] & - & - & $1(5.6)$ & - & - & - & $1(0.1)$ \\
\hline \multicolumn{8}{|l|}{ Non-typable strains } \\
\hline GNTP[NT] & - & $7(3.8)$ & - & $8(1.5)$ & - & - & $15(1.4)$ \\
\hline RV positive & $123(100)$ & $182(100)$ & $18(100)$ & $539(100)$ & $166(100)$ & $26(100)$ & $1054(100)$ \\
\hline
\end{tabular}

NT* not type.

prevalent from 2007 to 2010, G9P[8] in 2011, and G12P[8] in 2012 (Table 2).

Mixed infections were observed throughout the analyzed period $(62 / 1,054 ; 5.9 \%)$, and could be classified as single G-type with two or more P-types, multiple G-types with single P-type or multiple G- and P-types (Table 2). These strains are representative of those genotypes seen in single infections. RV strains with unusual G/P type combinations were also detected (27/1,054; 2.6\%), including G1P[4], G3P[4], and G9P[4]. Strains whose derivation may be associated with reassortment between animal and human strains were $4.8 \%(51 / 1,054)$, and infection with RV strains of animal origin represented $1.4 \%(15 / 1,054)$ of strains found (Table 2). Table 3 presents the numbers of mixed RV infections which could have given rise to particular unusual G/P type combinations by reassortment in nature. Using the data of Tables 2 and 3, no significant correlation was detected by linear regression analysis $(\mathrm{R}=0.638 ; \mathrm{N}=7)$. 
LUCHS, A.; CILLI, A.; MORILLO, S.G.; CARMONA, R.C.C. \& TIMENETSKY, M.C.S.T. - Rotavirus genotypes circulating in Brazil, 2007-2012: implications for the vaccine program. Rev. Inst. Med. Trop. Sao Paulo, 57(4): 305-13, 2015.

Table 3

Mixed RV infections that have possibly preceded the emergence of unusual genotypes

\begin{tabular}{|c|c|c|c|c|c|c|c|c|}
\hline \multirow{2}{*}{ Mixed type } & \multirow{2}{*}{ Total } & \multicolumn{7}{|c|}{ Unusual genotypes that possibly emerged from mixed infection } \\
\hline & & G1P[4] & G3P[4] & G9P [4] & G2P[6] & G8P[4] & G12P[4] & G12P[6] \\
\hline $\mathrm{G} 1 \mathrm{P}[4]+\mathrm{P}[8]$ & 1 & Yes & --- & --- & --- & --- & --- & --- \\
\hline G2P[4]+P[8] & 5 & --- & --- & --- & --- & --- & --- & --- \\
\hline G2P[4]+P[6] & 3 & --- & --- & --- & Yes & --- & --- & --- \\
\hline G3P[4]+P[6] & 1 & --- & Yes & --- & --- & --- & --- & --- \\
\hline G3P $[4]+P[8]$ & 1 & --- & Yes & --- & --- & --- & --- & --- \\
\hline G9P[4]+P[8] & 1 & --- & --- & Yes & --- & --- & --- & --- \\
\hline G9P[6]+P[8] & 1 & --- & --- & --- & --- & --- & --- & --- \\
\hline $\mathrm{G} 1+\mathrm{G} 2 \mathrm{P}[4]$ & 18 & Yes & --- & --- & --- & --- & --- & --- \\
\hline G1+G9P[8] & 3 & --- & --- & --- & --- & --- & --- & --- \\
\hline $\mathrm{G} 2+\mathrm{G} 3 \mathrm{P}[4]$ & 11 & --- & Yes & --- & --- & --- & --- & --- \\
\hline G2+G3P[8] & 2 & --- & --- & --- & --- & --- & --- & --- \\
\hline G2+G9P[4] & 1 & --- & --- & Yes & --- & --- & --- & --- \\
\hline G2+G9P[8] & 2 & --- & --- & --- & --- & --- & --- & --- \\
\hline $\mathrm{G} 2+\mathrm{G} 12 \mathrm{P}[4]$ & 1 & --- & --- & --- & --- & --- & Yes & --- \\
\hline $\mathrm{G} 2+\mathrm{G} 12 \mathrm{P}[8]$ & 1 & --- & --- & --- & --- & --- & --- & --- \\
\hline G2+G3+G9P[8] & 1 & --- & --- & --- & --- & --- & --- & --- \\
\hline $\mathrm{G} 1+\mathrm{G} 2+\mathrm{G} 3 \mathrm{P}[4]$ & 3 & Yes & Yes & --- & --- & --- & --- & --- \\
\hline G1+G9P[4]+P[8] & 1 & Yes & --- & Yes & --- & --- & --- & --- \\
\hline G2+G3P[4]+P[6] & 3 & --- & Yes & --- & Yes & --- & --- & --- \\
\hline G2+G3P[4]+P[8] & 2 & --- & Yes & --- & --- & --- & --- & --- \\
\hline Total & 62 & 23 & 21 & 3 & 6 & 0 & 1 & 0 \\
\hline
\end{tabular}

NOTE. The number of unusual G/P single infections were 4 G1P[4] infections, 22 G3P[4] infections, 1 G9P[4] infection, 1 G2P[6] infection, 5 G8P[4] infections, $1 \mathrm{G} 12 \mathrm{P}[4]$ infection, and $1 \mathrm{G} 12 \mathrm{P}[6]$ infection.

\section{DISCUSSION}

As universal RV vaccination continues to increase worldwide, global surveillance of RV has become an important focus of the vaccination programs. RV surveillance is vital to describe genotype distribution in different countries and their regions, and to discover potential development of new strains ${ }^{11}$. This study documents the high detection rate of G2P[4] strain in Brazil after RV vaccine introduction, as widely presented in previous studies ${ }^{8,32}$; however, also reveals a suggestive trend to be replaced by new RV strains (i.e. G9P[8] and G12P[8]) in the most recent years.

RV surveillance, considering the general population in Brazil, is patchy, and the majority of studies were performed among children under five years of age, even before vaccine introduction ${ }^{8,28,32,44}$. The frequency of RV infection detected in this work (19.1\%) was lower than global proportions (24.3\%), and those observed in studies carried out in other Latin America countries: Argentina (28.3\%), Bolivia (28.9\%), Chile (31.1\%), Colombia (30\%), Costa Rica (44.3\%), Ecuador (30.9\%), Guatemala (30.1\%), Panama (24.9\%), Paraguay (25.3\%), Peru (25.1), and Uruguay (37.5\%). Nevertheless, the frequency of RV infections was similar to that found in Mexico (19.9\%) and Nicaragua $(19.0 \%)^{28}$.

A previous study conducted in Sao Paulo, Brazil, (1996-2003) showed that the RV detection rate in the general population was $25 \%$. The present study (2007-2012) demonstrated a reduction in laboratoryconfirmed RV disease (19.1\%) in the country. This data is consistent with the decreasing burden of RV disease following vaccine introduction. RVs were detected less frequently $(19.5 \%)$ among children $\leq 5$ years of age than in older children and adolescents (6-18 years) (40.6\%). RV infection rates among children $\leq 5$ years will probably continue to decrease in future years, as successive birth cohorts are vaccinated ${ }^{11}$. Changes in the epidemiology of RV disease might occur in the post-licensing era, such as shifts in average age of infected person ${ }^{39}$. It has been observed in USA ${ }^{11}$ and Brazil $^{13}$ that RV disease tends to occur in older children after vaccine implementation. One possible explanation may be that the indirect protection of unvaccinated infants due to reduced RV transmission in the community (i.e. herd immunity), resulted in a larger susceptible cohort of unvaccinated older children that were not exposed to natural $\mathrm{RV}$ infection in previous seasons $\mathrm{s}^{2,11,47}$. Nonetheless, it is not yet possible 


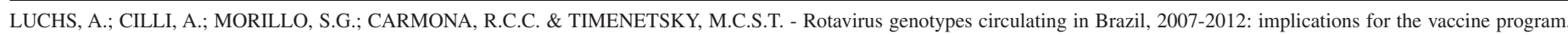
Rev. Inst. Med. Trop. Sao Paulo, 57(4): 305-13, 2015.

to predict whether the transmission of RV will persist in older age groups even with an increase in vaccine coverage among infants. $R V$ vaccination effects on household and community transmission will probably fluctuate as RV-susceptible children accumulate and become infected ${ }^{41}$.

On the other hand, post-vaccination records also indicate large reductions in RV disease among members of age groups who are too old to be vaccinated, suggesting that infants act as the primary carriers of infection $^{39}$. Indirect protection occurs as a result of decreased transmission of the infectious agent in the community, and amplifies the direct benefits of vaccination among both vaccinated and unvaccinated individuals ${ }^{3}$ which is a phenomenon that was not studied in the clinical trials of either vaccines ${ }^{41}$. Indirect benefits and/or harm from RV vaccination still need to be further explored.

RV infections occurred in the winter months (dry season) as usually observed in Brazil, especially in the South, Southeastern, and Midwest regions ${ }^{13}$. Curiously, a particular event was observed. The RV detection rate is usually concentrated between June and August in Brazil $^{7}$; nevertheless, the frequency of RV detection in this study peaked in September, i.e. at the beginning of the rainy season. The seasonal patterns and the influence of climate on many infectious diseases are well known ${ }^{40}$, and global warming is one of the environmental changes now under way. Nevertheless, it is still impossible to predict whether this climate variation could promote a wide range of impacts upon the occurrence of RV infection in the Brazilian population.

Alternatively, studies from various regions have also identified a remarkably consistent finding with regard to timing and spread of RV epidemics $^{39}$. Studies from USA and Belgium showed that a shift in the onset of epidemics by one to two months has taken place after RV vaccination $^{6,43}$. Regular annual epidemic dynamics could be driven by the accumulation of fully susceptible individuals (i.e. newborns) in the population, and widespread vaccination would be expected to reduce the number of fully susceptible individuals, thereby delaying the timing of RV activity and also potentially altering the seasonal pattern of RV activity across the country ${ }^{10}$. This hypothesis was tested in USA by CURNS et $a l .{ }^{10}$ and provides evidences that the spatiotemporal dynamics of RV activity are likely driven by the rate of accumulation of fully susceptible individuals rather than solely by environmental factors.

Considering RV annual frequency, a low percentage of RV infection was observed in 2009 (2.3\%). A similar lack of a RV season in Brazil during 2009 has been previously described ${ }^{13}$. The significant decrease observed in RV cases in 2009 was not accompanied by a decrease in the number of non-RV diarrhea cases, eliminating the possibility of bias due to specimen collection (http://portal.saude.gov.br/portal/arquivos/pdf/ casos_dda_16_04_2012.pdf, http://portal.saude.gov.br/portal/arquivos/ pdf/vigilanciadda.pdf). In the following 2010 season, however, Brazil experienced the resurgence of RV-associated cases, going back to the 2008 level of RV diarrhea cases. A substantial reduction in RV activity in one season followed by resurgence in the next season after vaccine introduction has been reported ${ }^{13,43}$. In addition, according to the National Meteorology Institute (INMET) records, during 2009, Brazil experienced an atypical rainy winter season with a higher average rainfall record due to the El Niño phenomenon (http://www.inmet.gov.br). Hypothetically, this climate condition could be involved in the low detection frequency observed.
Moreover, in 2009, the pandemic influenza A (H1N1) virus spread surprisingly quickly, and represented a significant challenge for Brazil's Surveillance Centers, as well as for the surveillance systems worldwide. A commitment between the new A/H1N1 pandemic response and the ability to continue surveillance efforts for other viruses, including RVs was found. A study conducted by COX et al. ${ }^{9}$ measured the impact of H1N1 influenza pandemic on the reporting of other events. The analysis revealed that the reporting of other threats dropped to a significantly lower rate, suggesting an important impact on the notification process of events during a period of extensive mobilization of public health resources ${ }^{9}$. It is noteworthy that a low detection rate was also observed in 2012 (3.1\%). However, the current study was conducted until June 2012 and therefore ended before the beginning of the RV season.

The genotyping results are comparable to recent published Brazilian pediatric surveillance genotyping data from 2007 to 2010, including the notably marked predominance of G2P[4] $]^{13}$. However, other common genotypes (G1P[8], G3P[8], G9P[8]) continued to circulate marginally over time, as observed in the Australian RV surveillance program ${ }^{23}$. The emergence of G2P[4] since 2006 has been reported in vaccinated populations in Australia (Rotarix ${ }^{\mathrm{TM}}$ and Rotateq ${ }^{\mathrm{TM}}$ ) and Nicaragua $\left(\text { Rotateq }^{\mathrm{TM}}\right)^{24,38}$, but also - to a lesser extent - in non-vaccinated populations ${ }^{14}$. The G2P[4] emergence and high prevalence probably follows a global trend dictated by natural oscillatory fluctuations of the most prevalent genotypes rather than being an effect of vaccination ${ }^{13}$.

Strains exhibiting the G8 genotype were identified in 2009, 2010, and 2011, following the sporadic identification of G8 strains as a cause of acute gastroenteritis in the Brazilian population during 2000-2004 ${ }^{46}$. The $\mathrm{P}[3]$ and $\mathrm{P}[9]$ types were also identified during the study period. In Brazil, previous reports found $\mathrm{P}[3]$ to be associated with $\mathrm{G} 3^{44}$, and $\mathrm{P}[9]$ with $\mathrm{G} 10^{46}$. Taken together these reports continue to highlight their low level existence in Brazilian inhabitants.

The present surveillance showed that genotype G9P[8] re-emerged as the dominant genotype in 2011 , representing $39.8 \%$ of all strains. Genotype G2P[4] was the second predominant type nationally, comprising $17.5 \%$ of all strains characterized. This survey highlights the ongoing fluctuations in the dominant genotypes and reveals the return of G9 as the dominant genotype in Brazil, similar to that observed in the early 2000s, in the pre-vaccine era ${ }^{7}$. In Australia, the parallel use of both vaccines provides a unique opportunity to compare the effect of each vaccine on the circulating wild type strains ${ }^{23}$. While the absolute numbers of RV-associated cases of acute gastroenteritis were reduced in all States, G2 and G9 strains were more prevalent in States using Rotarix ${ }^{\mathrm{TM}}$, whereas G3 strains were more prevalent in States using Rotateq ${ }^{\mathrm{TM} 25}$. The relatively high prevalence of G9 and G2 RV cases reported in 2011 may reflect a similar situation to that observed in Australia after Rotari $\mathrm{x}^{\mathrm{TM}}$ introduction. These differences do not necessarily imply a lack of protection against a particular type by either vaccine, but rather highlight the variation that can occur due to natural annual fluctuation in RV strain prevalence ${ }^{25}$.

In the present study, G12 was detected in $4.9 \%$ of total cases, being $20 \%$ in 2011 and $61.6 \%$ in 2012. Prior to 1998 , G12 was considered to be a rare type associated with human infections ${ }^{31,35}$. However, G12 in association with $\mathrm{P}[8]$ and $\mathrm{P}[6]$ is emerging worldwide ${ }^{31,35}$, and the high prevalence of G12 in the last two years of the present survey suggests that this type is emerging and circulating in the Brazilian population. 


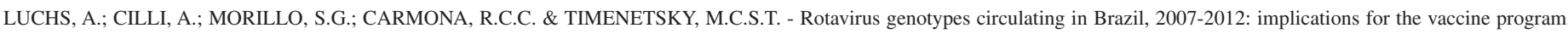
Rev. Inst. Med. Trop. Sao Paulo, 57(4): 305-13, 2015.

In South America, the presence of G12 associated with P[9] has been reported in Argentina, Brazil, and Paraguay ${ }^{29}$. The south region of Brazil borders with both Paraguay and Argentina, a fact that could indicate the spread of this strain within the southern cone of America by cross-border migration $^{29}$. In fact, the rapid emergence and global spread of G12 strain in less than a decade illustrates RV's potential to evolve ${ }^{23}$. Future studies needs to be carried out in order to access the real emergence of G12 strains in the country.

Mixed infections have been observed in many populations, including in Brazil ${ }^{1,734,44}$, and might be explained by natural reassortment of common strains $^{34}$. Curiously, in 2010, a high number of atypical mixed infections were observed. More mixed genotypes are found when many different genotypes co-circulate at the same time. This phenomenon is more common in countries in which a greater variation of different genotypes combinations is detected, such as in Brazil, but many will lead to evolutionary dead ends with only a few viral strains demonstrating fitness for transmission to population and emergence to become significant human pathogens ${ }^{20}$. In the series of samples described here, this was the case with G3P[4] strains emerging in significant numbers in 2010 (Tables 2 and 3). On the other hand, sampling intensity was very uneven during the years of observation. Thus, during 2010, more than $50 \%$ of the RV-positive samples were collected, about one third of this number in the years 2008 and 2011, and much less in the other years. Simply due to absolute numbers, the greatest diversity of RV G/P type combinations was found in 2010. Multiplex RT-PCRs for the identification of mixed infections should be used with caution. The possibilities of non-specific primer binding, different concentrations of RV strains, and risk of contamination (when handling several stool samples) have to be considered ${ }^{34}$.

Uncommon genotype combinations (G1P[4], G2P[6] or G9P[4]) were detected less frequently than in pre-vaccine periods ${ }^{7,44}$, thus suggesting a local decrease in strain diversity; unlike the latest data reported by the Australian RV surveillance program ${ }^{26}$. These less commonly found genotypes might be in vivo reassortants ${ }^{22,33}$. The number of mixed infections in our study was not correlated with the number of unusual genotypes, which suggests that the frequencies of particular mixed infections do not determine the frequencies of particular natural reassortants in Brazil; differing to those results observed in Israel $^{33}$. Uncommon RV types continue to be of worldwide interest because of the possible impact they may have on RV vaccine programs ${ }^{25}$.

G4P[8] RV strains are one of the most common combinations found in humans worldwide ${ }^{36,44}$; however, it was not detected in this study. On a global level, the weighted prevalence of G4 decreased slightly during 1996-2007 ${ }^{5,33}$. The seasonal shift of RV strains is a possible mechanism used by the virus to evade herd immunity acquired by previous infections, and thus, ultimately to persist in the human population ${ }^{37}$. The changing pattern of circulating RV types associated with greatly reduced diversity of strains may have important implications for the evolution of RV strains ${ }^{13}$. Moreover, in the present study, RV-positive samples could not be genotyped by multiplex RT-PCR. Untypable RVA strains have been reported in almost every epidemiological survey around the world, regardless of the methodology employed ${ }^{19}$. The number of untypable $\mathrm{G}$ type strains (50/1056) and P type (76/1056) was relatively high in the present study, considering the available technology nowadays and may suggest zoonotic transmission of animal RVs or RV genes for which there are no suitable primers in the diagnostic kits. In addition, many reports describe that certain PCR primers have become outdated since the primer binding sites mutated during co-circulation of wild type RVs over the years ${ }^{20,21}$.

The data obtained in the present study also suggested that adults and elderly are susceptible to the same types of RV during the same season of the year as children are, since no differences in the distribution of common, mixed, unusual or emerging RV strains were found among the distinct age groups. These findings highlight the need for continuing surveillance in both pediatric and mature populations to monitor the suitability of vaccines.

The present laboratory-based surveillance is not necessarily representative of the whole country; however the RV typing results from this survey, together with those of previous years, highlight the unpredictable nature of changes in the prevalence of RV strains across Brazil. In addition, the identification of rare or uncommon VP7 and VP4 genotypes further illustrates the diversity of strains capable of causing severe disease in the Brazilian population. Population level impact data could help to improve our understanding of RV transmission dynamics and the full potential of RV vaccines ${ }^{39}$. The rapidly changing genotype patterns do illustrate a more dynamic wild-type population, thus suggesting that vaccine pressure may be accelerating the selection process. This is supported by the observation of an increase in cases among older children, adolescents and adults during the current study period $^{26}$.

In countries with seasonal epidemics of RV and current vaccination program such as Brazil, surveillance should be extended to the months of the year when RV is not expected to fully understand the public health importance of shifts in average of cases and timing of epidemics ${ }^{39}$. Understanding the fluctuations in RV types using multi-center national surveillance, will provide valuable insights on vaccine efficacy over the next years. Rich genomic diversity along with the detection of unusual and mixed strains in Brazil further increases the chances of evolution of more novel strains.

\section{RESUMO}

\section{Genótipos de rotavírus circulando no Brasil, 2007-2012: implicações para o Programa de Vacinação}

Em relação à saúde pública no Brasil, um novo cenário emergiu com o estabelecimento dos programas universais de vacinação contra o rotavírus (RV). Os resultados de cinco anos (2007-2012) de vigilância dos genótipos $\mathrm{G}$ e $\mathrm{P}$ de cepas de RV detectadas em indivíduos com gastroenterite aguda no Brasil são descritos no presente estudo. Um total de 6196 amostras fecais foi investigado utilizando ELISA e RT-PCR. RVs foram detectados em 19,1\% (1181/6196). O pico de incidência de RV se deslocou de junho-agosto para setembro. RV foi detectado com menor frequência entre crianças $\leq 5$ anos $(19,5 \%)$ quando comparado às crianças mais velhas e adolescentes (6-18 anos) (40,6\%). A distribuição genotípica mostrou um perfil diferente a cada ano: a cepa G2P[4] foi prevalente durante 2007-2010, G9P[8] em 2011 e G12P[8] em 2012. Infecções mistas (G1+G2P[4], G2+G3P[4]+P[8], G2+G12P[8]), combinações não usuais (G1P[4], G2P[6]) e cepas atípicas (G3P[3]) também foram identificadas em todo o período do estudo. A vacinação em massa pode 
LUCHS, A.; CILLI, A.; MORILLO, S.G.; CARMONA, R.C.C. \& TIMENETSKY, M.C.S.T. - Rotavirus genotypes circulating in Brazil, 2007-2012: implications for the vaccine program. Rev. Inst. Med. Trop. Sao Paulo, 57(4): 305-13, 2015.

alterar o padrão sazonal do RV. A tendência do RV em infectar crianças mais velhas e adolescentes após a implementação da vacina tem sido relatada em todo o mundo. A emergência de G2P[4] segue provavelmente a tendência mundial e, aparentemente, não está relacionada à vacinação. G12 também parece estar emergindo na população brasileira. As rápidas mudanças nos padrões de genótipos dos RVs observados durante o período desse estudo ilustram a existência de uma população dinâmica de cepas selvagens co-circulando no Brasil.

\section{ACKNOWLEDGMENTS}

We thank the Adolfo Lutz Institute's Enteric Diseases Laboratory staff: Adeline de Mira Fernandes, Carolina Jeannine Gill, Bethânia Costa Vilanova, Cibele Daniel Ribeiro, Débora de Souza Gregório and Heloisa Rosa Vieira for laboratorial analysis assistance; Antonio Erculiani Junior and Sirlene Henrique Rodrigues Silva for technical assistance. We are grateful to Centers for Surveillance (CVE), Sao Paulo State Health Department; Public Health Laboratories (LACENs) and CGLAB/DEVEP/SVS/Ministry of Health, Brasilia, for assistance in sample collection and epidemiological data.

\section{AUTHORS' CONTRIBUTIONS}

AL and MCSTT conceived the study. AL, RCCC and MCSTT designed the study protocol; AL, AC, SGM, RCCC and MCSTT participated in the conduct of the study; AL, AC and SGM acquired the data, performed the immunoenzymatic assays, and the molecular typing of the strains; AL and MCSTT analyzed and interpreted the data; AL and MCSTT drafted the manuscript; AC, SGM, RCCC critically revised the manuscript for intellectual content. All authors read and approved the final version. AL and MCSTT are guarantors of the paper.

\section{FUNDING}

None.

\section{COMPETING INTEREST}

None to declare.

\section{ETHICAL APPROVAL}

This study was carried out in accordance with the Declaration of Helsinki as revised in 2000, and approved by the Ethics Committee of the Adolfo Lutz Institute, Sao Paulo, Brazil. Study participants were not required to provide informed consent as this study was considered by the Ethics Committee to be part of routine surveillance activities.

\section{REFERENCES}

1. Ahmed MU, Urasawa S, Taniguchi K, Urasawa T, Kobayashi N, Wakasugi F, et al. Analysis of human rotavirus strains prevailing in Bangladesh in relation to nationwide floods brought by the 1988 monsoon. J Clin Microbiol. 1991;29:2273-9.

2. Anderson EJ, Shippee DB, Weinrobe MH, Davila MD, Katz BZ, Reddy S, et al. Indirect protection of adults from rotavirus by pediatric rotavirus vaccination. Clin Infect Dis. 2013;56:755-60.

3. Anderson RM, May RM. Immunisation and herd immunity. Lancet. 1990;335(8690):641-
4. Armah GE, Hoshino Y, Santos N, Binka F, Damanka S, Adjei R, et al. The global spread of rotavirus G10 strains: detection in Ghanaian children hospitalized with diarrhea. J Infect Dis. 2010;202(Suppl): S231-8.

5. Bányai K, László B, Duque J, Steele AD, Nelson EA, Gentsch JR, et al. Systematic review of regional and temporal trends in global rotavirus strain diversity in the pre rotavirus vaccine era: insights for understanding the impact of rotavirus vaccination programs. Vaccine. 2012;30(Suppl 1):A122-30.

6. Braeckman T, Van Herck K, Raes M, Vergison A, Sabbe M, Van Damme P. Rotavirus vaccines in Belgium: policy and impact. Pediatr Infect Dis J. 2011;30(1 Suppl): S21-4.

7. Carmona RC, Timenetsky M do C, Morillo SG, Richtzenhain LJ. Human rotavirus serotype G9, São Paulo, Brazil, 1996-2003. Emerg Infect Dis. 2006;12:963-8.

8. Carvalho-Costa FA, Volotão E de M, de Assis RM, Fialho AM, de Andrade J da S, Rocha LN, et al. Laboratory-based rotavirus surveillance during the introduction of a vaccination program, Brazil, 2005-2009. Pediatr Infect Dis J. 2011;30(1 Suppl):S35-41.

9. Cox A, Guglielmetti P, Coulombier D. Assessing the impact of the 2009 H1N1 influenza pandemic on reporting of other threats through the Early Warning and Response System. Euro Surveill. 2009;14:19397.

10. Curns AT, Panozzo CA, Tate JE, Payne DC, Patel MM, Cortese MM, et al. Remarkable postvaccination spatiotemporal changes in United States rotavirus activity. Pediatr Infect Dis J. 2011;30(1 Suppl):S54-5.

11. Desai R, Curns AT, Steiner CA, Tate JE, Patel MM, Parashar UD. All-cause gastroenteritis and rotavirus-coded hospitalizations among US children, 2000-2009. Clin Infect Dis. 2012;55:e28-34.

12. do Carmo GM, Yen C, Cortes J, Siqueira AA, de Oliveira WK, Cortez-Escalante JJ, et al. Decline in diarrhea mortality and admissions after routine childhood rotavirus immunization in Brazil: a time-series analysis. PLOS Med. 2011;8:e1001024.

13. Dulgheroff AC, Figueiredo EF, Moreira LP, Moreira KC, Moura LM, Gouvêa VS, et al. Distribution of rotavirus genotypes after vaccine introduction in the Triângulo Mineiro region of Brazil: 4-year follow-up study. J Clin Virol. 2012;55:67-71.

14. Esteban LE, Rota RP, Gentsch JR, Jiang B, Esona M, Glass RI, et al. Molecular epidemiology of group A rotavirus in Buenos Aires, Argentina 2004-2007: reemergence of G2P[4] and emergence of G9P[8] strains. J Med Virol. 2010;82:108393.

15. Flannery B, Samad S, de Moraes JC, Tate JE, Danovaro-Holliday MC, de Oliveira LH, et al. Uptake of oral rotavirus vaccine and timeliness of routine immunization in Brazil's National Immunization Program. Vaccine. 2013;31:1523-8.

16. Gentsch JR, Glass RI, Woods P, Gouvea V, Gorziglia M, Flores J, et al. Identification of group A rotavirus gene 4 types by polymerase chain reaction. J Clin Microbiol. 1992;30:1365-73.

17. Gouvea V, Glass RI, Woods P, Taniguchi K, Clark HF, Forrester B, et al. Polymerase chain reaction amplification and typing of rotavirus nucleic acid from stool specimens. J Clin Microbiol. 1990;28:276-82.

18. Gouvea V, Santos N, Timenetsky M do C. VP4 typing of bovine and porcine group A rotaviruses by PCR. J Clin Microbiol. 1994;32:1333-7.

19. Honma S, Chizhikov V, Santos N, Tatsumi M, Timenetsky M do C, Linhares AC, et al. Development and validation of DNA microarray for genotyping group A rotavirus VP4 (P[4], P[6], P[8], P[9], and P[14]) and VP7 (G1 to G6, G8 to G10, and G12) genes. J Clin Microbiol. 2007;45:2641-8.

20. Iturriza-Gómara M, Dallman T, Bányai K, Böttiger B, Buesa J, Diedrich S, et al. Rotavirus genotypes co-circulating in Europe between 2006 and 2009 as determined by EuroRotaNet, a pan-European collaborative strain surveillance network. Epidemiol Infect. 2011;139:895-909. 

Rev. Inst. Med. Trop. Sao Paulo, 57(4): 305-13, 2015.

21. Iturriza-Gómara M, Green J, Brown DW, Desselberger U, Gray JJ. Diversity within the VP4 gene of rotavirus P[8] strains: implications for reverse transcription-PCR genotyping. J Clin Microbiol. 2000;38:898-901.

22. Iturriza-Gómara M, Isherwood B, Desselberger U, Gray J. Reassortment in vivo: driving force for diversity of human rotavirus strains isolated in the United Kingdom between 1995 and 1999. J Virol. 2001;75:3696-705.

23. Kirkwood CD, Boniface K, Bishop RF, Barnes GL. Australian Rotavirus Surveillance Program: annual report, 2009/2010. Commun Dis Intell Q Rep. 2010;34:427-34.

24. Kirkwood CD, Boniface K, Bishop RF, Barnes GL, Australian Rotavirus Surveillance Group. Australian Rotavirus Surveillance Program annual report, 2008/2009. Commun Dis Intell Q Rep. 2009;33:382-8.

25. Kirkwood CD, Cannan D, Boniface K, Bishop RF, Barnes GL, Australian Rotavirus Surveillance Group. Australian Rotavirus Surveillance Program annual report, 2007/08. Commun Dis Intell Q Rep. 2008;32:425-9.

26. Kirkwood CD, Roczo S, Boniface K, Bishop RF, Barnes GL, Australian Rotavirus Surveillance Group. Australian Rotavirus Surveillance Program annual report, 2010/11. Commun Dis Intell Q Rep. 2011;35:281-7.

27. Li B, Clark HF, Gouvea V. Nucleotide sequence of the VP4-encoding gene of an unusual human rotavirus (HCR3). Virology. 1993;196:825-30.

28. Linhares AC, Stupka JA, Ciapponi A, Bardach AE, Glujovsky D, Aruj PK, et al. Burden and typing of rotavirus group A in Latin America and the Caribbean: systematic review and meta-analysis. Rev Med Virol. 2011;21:89-109.

29. Martínez M, Amarilla AA, Galeano ME, Aquino VH, Fariña N, Russomando G, et al Predominance of rotavirus G2P[4] and emergence of G12P[9] strains in Asunción, Paraguay, 2006-2007. Arch Virol. 2010;155:525-33.

30. Matthijnssens J, Ciarlet M, McDonald SM, Attoui H, Bányai K, Brister JR, et al. Uniformity of rotavirus strain nomenclature proposed by the Rotavirus Classification Working Group (RCWG). Arch Virol. 2011;156:1397-413.

31. Matthijnssens J, Heylen E, Zeller M, Rahman M, Lemey P, Van Ranst M. Phylodynamic analyses of rotavirus genotypes G9 and G12 underscore their potential for swift global spread. Mol Biol Evol. 2010;27:2431-6.

32. Morillo SG, Luchs A, Cilli A, Costa FF, Carmona R de C, Timenetsky M do C Characterization of rotavirus strains from day care centers: pre- and post-rotavirus vaccine era. J Pediatr (Rio J). 2010;86:155-8

33. Muhsen K, Shulman L, Rubinstein U, Kasem E, Kremer A, Goren S, et al. Incidence, characteristics, and economic burden of rotavirus gastroenteritis associated with hospitalization of israeli children $<5$ years of age, 2007-2008. J Infect Dis. 2009;200(Suppl 1):S254-63.

34. Nielsen NM, Eugen-Olsen J, Aaby P, Mølbak K, Rodrigues A, Fischer TK. Characterisation of rotavirus strains among hospitalised and non-hospitalised children in Guinea-Bissau, 2002: a high frequency of mixed infections with serotype G8. J Clin Virol. 2005;34:13-21.
35. Page NA, de Beer MC, Seheri LM, Dewar JB, Steele AD. The detection and molecular characterization of human G12 genotypes in South Africa. J Med Virol. 2009;81:106 13 .

36. Parashar UD, Gibson CJ, Bresse JS, Glass RI. Rotavirus and severe childhood diarrhea. Emerg Infect Dis. 2006;12:304-6.

37. Parra GI. Seasonal shifts of group A rotavirus strains as a possible mechanism of persistence in the human population. J Med Virol. 2009;81:568-71

38. Patel M, Pedreira C, De Oliveira LH, Tate J, Orozco M, Mercado J, et al. Association between pentavalent rotavirus vaccine and severe rotavirus diarrhea among children in Nicaragua. JAMA. 2009;301:2243-51.

39. Patel MM, Steele D, Gentsch JR, Wecker J, Glass RI, Parashar UD, et al. Real-world impact of rotavirus vaccination. Pediatr Infect Dis J. 2011;30(1Suppl):S1-5.

40. Patz JA, Epstein PR, Burke TA, Balbus JM. Global climate change and emerging infectious diseases. JAMA. 1996;275:217-23.

41. Payne DC, Staat MA, Edwards KM, Szilagyi PG, Weinberg GA, Hall CB, et al. Direct and indirect effects of rotavirus vaccination upon childhood hospitalizations in 3 US Counties, 2006-2009. Clin Infect Dis. 2011;53:245-53.

42. Tate JE, Burton AH, Boschi-Pinto C, Steele AD, Duque J, Parashar UD, et al. 2008 estimate of worldwide rotavirus-associated mortality in children younger than 5 years before the introduction of universal rotavirus vaccination programmes: a systematic review and meta-analysis. Lancet Infect Dis. 2012;12:136-41.

43. Tate JE, Mutuc JD, Panozzo CA, Payne DC, Cortese MM, Cortes JE, et al. Sustaine decline in rotavirus detections in the United States following the introduction of rotavirus vaccine in 2006. Pediatr Infect Dis J. 2011;30(1 Suppl):S30-4

44. Timenetsky M do C, Santos N, Gouvea V. Survey of rotavirus G and P types associated with human gastroenteritis in São Paulo, Brazil, from 1986 to 1992. J Clin Microbiol. $1994 ; 32: 2622-4$

45. Trojnar E, Sachsenröder J, Twardziok S, Reetz J, Otto PH, Johne R. Identification of an avian group A rotavirus containing a novel VP4 gene with a close relationship to those of mammalian rotaviruses. J Gen Virol. 2013;94:136-42.

46. Volotão EM, Soares CC, Maranhão AG, Rocha LN, Hoshino Y, Santos N. Rotavirus surveillance in the city of Rio de Janeiro-Brazil during 2000-2004: detection of unusual strains with G8P[4] or G10P[9] specificities. J Med Virol. 2006;78:263-72.

47. Yi J, Anderson EJ. Rotavirus vaccination: short-term indirect herd protection, long-term uncertainty. Expert Rev Vaccines. 2013;12:585-7.

48. Widdowson MA, Steele D, Vojdani J, Wecker J, Parashar U. Global rotavirus surveillance: determining the need and measuring the impact of rotavirus vaccines. J Infect Dis. 2009;200(Suppl 1):S1-8

Received: 23 July 2014

Accepted: 13 November 2014 


\section{Revista do Instituto de Medicina Tropical de São Paulo on line.}

Publications from 1984 to the present data are now available on:

http://www.scielo.br/rimtsp

PAST ISSUES FROM 1959 ON (PDF)

www.imt.usp.br/portal/

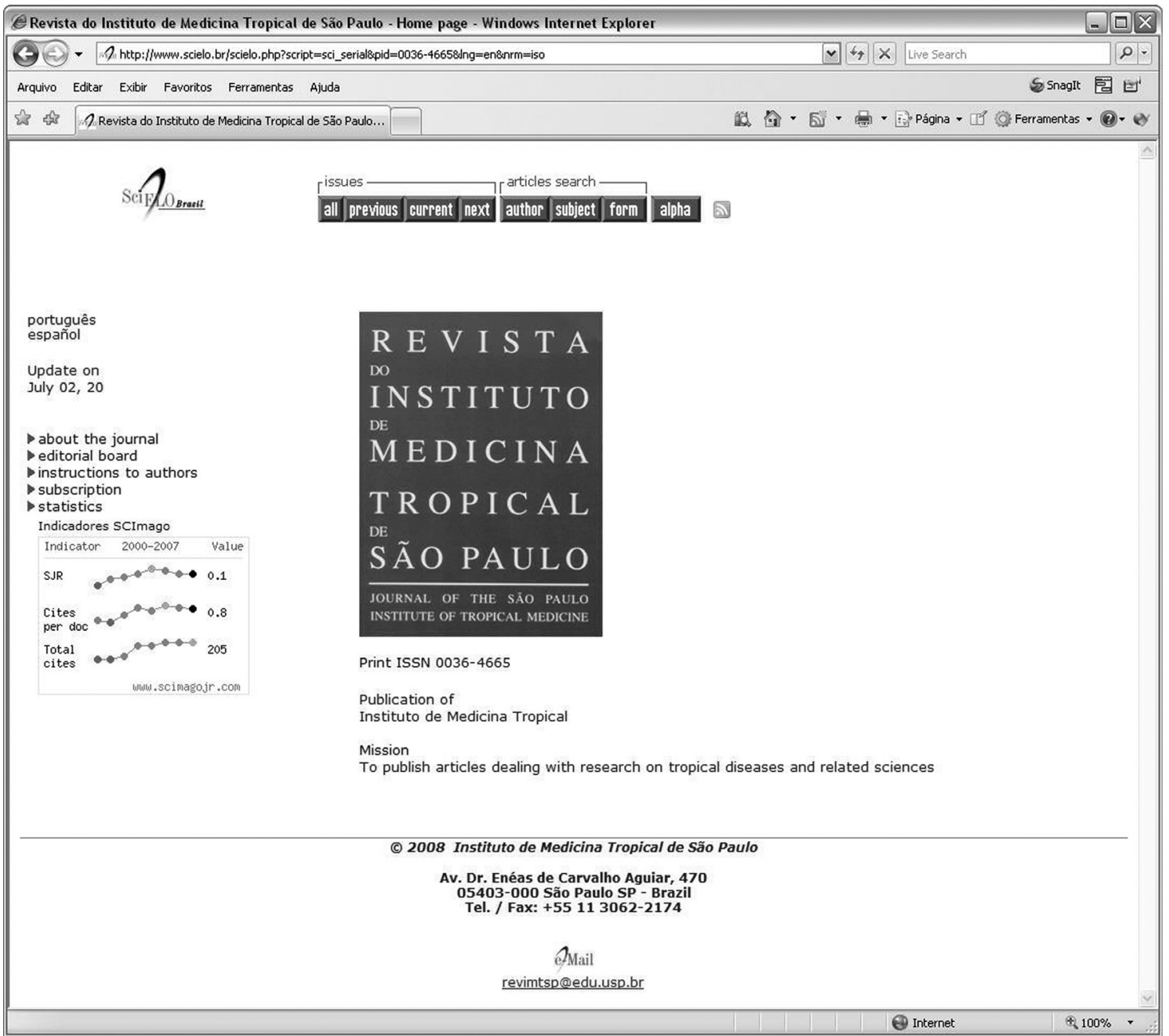

SciELO - The Scientific Electronic Library OnLine - SciELO is an electronic virtual covering a selected collection of Brazilian scientific journals.

The library is an integral part of a project being developed by FAPESP - Fundação de Amparo à Pesquisa do Estado de São Paulo, in partnership with BIREME - the Latin American and Caribbean Center on Health Sciences Information.

SciELO interface provides access to its serials collection via an alphabetic list of titles or a subject index or a search by word of serial titles, publisher names, city of publication and subject.

The interface also provides access to the full text of articles via author index or subject index or a search form on article elements such as author names, words from title, subject and words from full text.

FAPESP/BIREME Project on Scientific Electronic Publications Latin American and Caribbean Center on Health Sciences Information

Rua Botucatu 862 - 04023-901 São Paulo, SP - Brazil

Tel. (011) 5576-9863

scielo@bireme.br 